\title{
INFLUENCE OF ARBUSCULAR MYCORRHIZAL FUNGI AND SOIL AMELIORANTS ON THE MYCORRHIZAL COLONIZATION, CHLOROPHYLL CONTENT, AND PERFORMANCE GROWTH OF TWO TROPICAL TREE SEEDLINGS GROWN IN SOIL MEDIA WITH HIGH ALUMINUM CONTENT
}

\author{
SRI WILARSO BUDI*, BUDI ARTY, BASUKI WASIS, CAHYO WIBOWO and ANDI SUKENDRO \\ Department of Silviculture, Faculty of Forestry, IPB University, Indonesia \\ Jalan Lingkar Akademik Kampus IPB Dramaga, Bogor 16680, West Java, Indonesia \\ *E-mail: wilarso62@yahoo.com
}

Accepted 6 February 2020, Published online 30 June 2020

\begin{abstract}
Aluminum is one of heavy metals and its availability is correlated with low soil $\mathrm{pH}$, such as in acidic soil as well as post mining soil and become limiting factors for plant growth. MycoSilvi is a biofertilizer inoculant product containing arbuscular mycorrhizal fungi enriched with Mycorrhizal Helper Bacteria's (MHBs) designed for improving plant growth on post-mining soil media with low $\mathrm{pH}$ and high aluminum content. This study was conducted to determine the potential use of three variants of MycoSilvi, both single or in combination with soil ameliorant to enhance Albizia chinensis (Osbeck) Merrill and Pongamia pinnata (L.) Pierre growth. This study was conducted by randomized complete design with factorial scheme in a greenhouse for 4 months. The first factor consisted of four different levels based on MycoSilvi (M) inoculation: control (M0); MycoSilvi variant 1 (M1), MycoSilvi variant 2 (M2) and MycoSilvi variant 3 (M3). The second factor consisted of four levels based on the addition of lime and compost to soil medium: control (L0C0), addition of lime (L1C0), addition of compost (L0C1) and addition of lime and compost (L1C1). Data was analyzed using analysis of variance (ANOVA). Total chlorophyll content as indicated by leaf greenness index, height, steam diameter, biomass, root colonization and $\mathrm{P}$ accumulation on both plant species were observed after 12 weeks of planting. The results showed that the MycoSilvi inoculation differently colonized the roots and increased P uptake, leaf greenness index and growth of both plants species. The addition of lime and compost increased the mycorrhizal roots colonization, P uptake, leaf greenness index and plant growth of both plants' species. The best result was obtained from the combination treatment of MycoSilvi variant 3, lime and compost.
\end{abstract}

Key words: Acid soil, aluminum, MycoSilvi, plant growth, post mining soil

\section{INTRODUCTION}

Aluminum is a micronutrient needed by plant in small amounts. It plays an important role as cofactors for activating enzyme in the metabolism processes (Zatta et al., 2000). The availability of Aluminium in the soil is greatly affected by soil pH (Dong et al., 1995). In acidic soil the availability of Aluminium in the soil is very large and become toxic for plant growth (Delhaize \& Ryan, 1995). In the tropic regions, acidic soil is very abundant, commonly ultisol and oxisol. There are about 500 million hectares $(16.2 \%)$ of the African continent covered by acidic soil (Bationo et al., 2006) and

\footnotetext{
* To whom correspondence should be addressed.
}

according to Van Uexkull and Bosshart (1989) about $38 \%$ of upland soil in Southeast Asia is covered by ultisol and oxisol. Subagyo et al. (2004), stated that in Indonesia, acidic soil covers almost $25 \%$ of land surface, which spreads in Kalimantan, Sumatera, Maluku, Papua, Sulawesi, Java and Nusa Tenggara. The acidic soil commonly is not able to support plant growth and development normally because they are not only high in aluminum content but also low nutrient content, high Mn toxicity, low organic matter and biodiversity and very low mineralization and nitrification (Kochian et al., 2004). The high concentration of Aluminum overburdens soil at coal mine, inhibits the plant growth and chlorophyll content of Pongomia pinata in the nursery (Agus et al., 2019). The mining activity may alter the soil 
pH as reported by Hudson et al. (1999), that affects some environmental impacts such as development of acidic soils and waters, erosion of tailings by wind and water, and physical disturbances to the landscape. Mining activities also increase toxic elements to plants such as $\mathrm{Al}, \mathrm{Fe}, \mathrm{Mn}, \mathrm{Ni}, \mathrm{Zn}, \mathrm{Co}$ and $\mathrm{Cd}$ as reported by Wahab and Marikar (2012). Thus, all acidic soil characteristics become a major constrain for plant growth and productivity. Numerous efforts have been made for improving chemical characteristic of acidic soil (Anetor \& Akinrinde, 2007). The use of lime in acidic soil and adition of Phosphorous can reduced aluminium toxicity and improve plant growth (Muindi et al., 2015). According to Novak et al. (2018), the addition of lime and biochar to acid soils can have a direct effect on metal availability, soil enzyme activity and plant growth. The application of lime and compost in acidic soil is also effective at reducing shoot Mn content of test plant (Chung \& $\mathrm{Wu}, 2008)$. Lime and compost also can reduce $\mathrm{Al}$ toxicity and increase soil $\mathrm{pH}$ in acidic soil (Teshome et al., 2017).

Arbuscular Mycorrhizal Fungi (AMF) a symbiotic organism plays an important role in sustainable soil-plant system (Hause \& Fester, 2005), and have potential role in the restoration of degraded lands including post mine lands (Asmelash et al., 2016; Wulandari et al., 2016). These fungi have been widely used for improving plant growth and development in degraded lands (Maulana et al., 2017) and acidic soil as they have numerous benefits to the plant, including increased absorption of phosphours nutrition in acidic soil (Smith et al., 2011), better Nitrogen and Potassium uptake (Bucking \& Kafle, 2015; Sharma et al., 2017), producing enzyme and plant growth hormones (Bini et al., 2017; Foo et al., 2013), defending root against soil borne diseases (Bakhtiar et al., 2010) and increasing plant growth and productivity (Baum et $a l ., 2015)$. In the soil-plants systems, AMF interact positively with coal waste and wood charcoal to increase plant growth (Budi \& Christina, 2013; Budi \& Setyaningsih, 2013), however little data is available on the interactions of lime, compost and AMF in soil-plants systems in acidic soil.

Leguminous trees are known to be very responsive to AMF inoculation (Maulana et al., 2017) and widely used for reforestation in Indonesia. Albizia chinensis (Osbeck) Merrill and Pongamia pinnata (L.) Pierre are potential plants for the rehabilitation of degraded land. A. chinensis well adapted in poor soil and categorized as a pioneer species in reforestation programme (Manjaribe et al., 2013). The bark contains flavonoids, alkaloids, saponins and proteins, which were used as a medicine (Amudha et al., 2017). $P$. pinnata is a fast growing tree and adapt well in acidic soil and well-drained, lateral roots are numerous and well developed (Bhalerao \& Sharma, 2014). This species matures after 4-7 years and produced fruits, which has potential for biodiesel (Karmee \& Chadha, 2005). The seeds of P. pinnata contain several secondary metabolites having pharmaceutical activity (Yadav et al., 2011).

Our laboratory developed a biological fertilizer named MycoSilvi, an Arbuscular Mycorrhizal Fungi incoculum containing Glomus mosseae enriched with Mycorrhizal Helper Bacterias (MHBs). Previous research showed that MycoSilvi improves three species of forest tree grown in marginal soil (Jayani et al., 2018). Severals variants of MycoSilvi inoculum have been produced and tested in Falcataria molucaana seedling (Budi et al., 2020). In this research the same MycoSilvi variant was tested in $A$. chinensis and $P$. pinata seedlings were grown in soil medium originally from silica post mining area with low $\mathrm{pH}$ and high aluminium content. The aim of this research is to test MycoSilvi variants and soil ameliorant (lime and compost) separately or in combination in improving $A$. chinensis and $P$. pinnata growth in soil medium with low $\mathrm{pH}$ and high aluminium content.

\section{MATERIALS AND METHODS}

\section{Soil and soil ameliorant}

The top soil (0-20 cm depth) was collected from silica post mining area in Cibadak, Sukabumi District West Jawa (06 $55^{\prime} 18.1^{\prime \prime} \mathrm{S}$ and $106^{\circ} 47^{\prime} 10.8^{\prime \prime}$ E). The soil was then transported to Laboratory, air dried, sieved $(2 \mathrm{~mm})$. The chemical properties of soil were analysed following standard method in Soil Laboratory, Department of Soil Science and Land Resources, Faculty of Agriculture Bogor Agriculture University. The chemical properties of soil medium are $\mathrm{pH} \mathrm{H}_{2} \mathrm{O}=3.20$; C-organic (Walkley \& Black) = $4.1 \%$; N-Total $($ Kjeldhal $)=0.19 \% ; \mathrm{C} / \mathrm{N}=22.15 ; \mathrm{P}$ $($ Bray I $)=13.78 ; \mathrm{P}(\mathrm{HCl} 25 \%)=278.04 \mathrm{ppm}$ and Al-dd $=690 \mathrm{mg} / \mathrm{kg}$. Lime and compost were widely used as soil ameliorant (Bekele et al., 2018; Haynes $\&$ Naidu, 1998). Lime was obtained from the farmers market as dolomite. Compost with the trade name of agro flower was produced by CV. Laksmi Prima Bogor Indonesia. The characteristics of compost are: $\mathrm{pH} 7.71$; C-organic 48.79\%; N $0.58 \%$; K $1.00 \%$ and $\mathrm{P}_{2} 0_{5} 2.90 \%$ that was determined at Soil Laboratory, Department of Soil Science and Land Resources, Faculty of Agriculture Bogor Agriculture University. The soil was sterilized by autoclaving at $121^{\circ} \mathrm{C}$ for 1 hour. The sterilized soil was than mixed with lime and compost in accordance with the treatment. 


\section{Seedling and MycoSilvi inoculum}

Seeds of Albizia chinensis (Osbeck) Merrill and Pongamia pinnata (L.) Pierre was obtained from Center of Research and Development for Forest Seed, Bogor Indonesia. The nature of both seeds is orthodox. Seeds were soaked in hot water $\left(80^{\circ} \mathrm{C}\right)$ for one hour and than soaked in cold water for 24 hours. The seeds than shown in plastict box containing sterilized zeolite and placed in green house for two weeks and watered as needed. The percentage of germination in both species was above $85 \%$. Glomus moseae and Acaulosphora sp. were isolated from the rhizosphere of Anthocepalus cadamba, in Madiun District East Java (Budi \& Dewi, 2016). Gigaspora margarita was isolated from primary forest, in Batanghari District, Jambi Province, Indonesia (Sahner et al., 2015). MycoSilvi was produced in sterilized zeolite medium with Puiraria javanica as host plant for two months (Jayani et al., 2018) in the green house, with the daily temperature of $29^{\circ} \mathrm{C}-35^{\circ} \mathrm{C}$ and relative humidity of $60-90 \%$. There were three variants of MycoSilvi produced. MycoSilvi variant 1, containing Glomus mossea Gerd and Trappe; MycoSilvi variant 2, containing G. mossea and Acaulospora sp. and MycoSilvi variant 3, containing G. mosseae, Acaulospora sp. and Gigaspora margarita Becker and Hall.

\section{MycoSilvi Inoculation}

Two weeks old uniform $A$. chinensis and $P$. pinnata seedlings were transplanted into $500 \mathrm{ml}$ polybag containing sterilized mixed silica post mining soil and soil ameliorant. Five grams of fresh MycoSilvi inoculum containing environ 50 spores, mycelium, and mycorrhizal roots and MHBs were placed near the roots seedling at transplanting. $A$. chinensis and $P$. pinnata seedlings without MycoSilvi inoculation was prepared as control. Plants were grown for twelve weeks in the green house and watered as needed.

\section{Harvesting and parameter measurement}

Plant height $(\mathrm{cm})$ and steam diameter $(\mathrm{mm})$ were measured at two weeks I interval until twelve weeks old. Plant height was measured using meter rule from plant base to upper tip of the plant. Plant steam diameter was measured by digital caliper at $1 \mathrm{~cm}$ above the base of the seedlings stems. At twelve weeks old, SPAD chlorophyll meter was used to measure leaf chlorophyll content. Roots were sampled before harvest for evaluating their mycorrhizal colonization. Mycorrhizal colonization was evaluated according to the method of Clapp et al. (1996). Percentage of mycorrhizal colonization was determined according to the method of O'connor et al. (2001). Plants were harvested twelve weeks after planting and evaluated for their biomass (g). Biomass weight was recorded after drying at $70^{\circ} \mathrm{C}$ to constant weight is attained. Biomass $\mathrm{P}$ concentration was determined at Soil Laboratory, Department of Soil Science and Land Resources, Faculty of Agriculture Bogor Agriculture University. $P$ accumulations was calculated by multiplying biomass $\mathrm{P}$ concentration by biomass dry weight.

\section{Experiment design}

The experiment was done with factorial design with 2 factors, MycoSilvi and Soil ameliorant. The MycoSilvi (M) has four levels (M0 = uninoculated, M1 = MycoSilvi variant 1, M2 = MycoSilvi variant 2 and M3 = MycoSilvi variant 3), and soil ameliorant (LC) have 4 levels (L0C0 $=$ Lime $0 \mathrm{~g}$ and Compost $0 \mathrm{~g}, \mathrm{~L} 1 \mathrm{C} 0=$ Lime 2.078 and Compost $0 \mathrm{~g}, \mathrm{~L} 0 \mathrm{C} 1=$ Lime $0 \mathrm{~g}$ and Compost $20 \mathrm{~g}, \mathrm{~L} 1 \mathrm{C} 1=$ Lime $2.078 \mathrm{~g}$ and Compost $20 \mathrm{~g}$ ). The experiment was arranged in a completely randomized design in a polybag culture with 5 replicates. Analysis of Variance Procedure analyzed all of the data.

\section{RESULTS AND DISCUSSION}

\section{Arbuscular Mycorrhizal colonization}

AM Fungi colonized all seedlings of $A$. chinensis and $P$. pinnata. No AM Fungi colonization was observed in all control plants (Table 1). The single factor of MycoSilvi inoculation significantly affected the arbuscular mycorrhizal colonization of the roots of $A$. chinensis and $P$. pinnata. A. chinensis seedling inoculated with MycoSilvi variant 3 had higher AM colonization than that inoculated with MycoSilvi variant 1 and 2 , while $P$. pinnata seedling inoculated with MycoSilvi variant 2 had higher AM colonization than that inoculated with MycoSilvi variant 3 and 1 (Table 1), indicating that AM mycorrhizal colonizatioan is affected by plant species as reported by Halder et al. (2015). The single factor of soil ameliorant significantly influences the mycorrhizal colonization in both tropical tree seedlings. Lime increased AM mycorrhizal roots colonization in $A$. chinensis seedling inoculated with MycoSilvi variant 1, 2 and 3 increased by $350 \%, 350 \%$ and $875 \%$ respectively, while compost increased by $525 \%, 75 \%$ and $180 \%$ respectively. Lime also increased AM mycorrhizal roots colonization in $P$. pinata seedling inoculated with MycoSilvi variant 1 , and 3 by $100 \%$ and $114 \%$ respectively, while $P$. pinata inoculated with MycoSilvia variant 2, lime had a negative effect, it decreased the AM mycorrhizal roots colonization by $33 \%$ (Table 1). Compost had a positive effect on AM mycorrhizal roots colonization of $P$. pinata which increased by $333 \%, 55.6 \%$ and $100 \%$ when inoculated with MycoSilvi variant 1, 2 and 3 respectively. 
Table 1. Effect of MycoSilvi and soil ameliorant on mycorrhizal colonization and $\mathrm{P}$ absorption of $A$. chinensis and $P$. pinnata (12 weeks after planting)

\begin{tabular}{|c|c|c|c|c|}
\hline \multirow{2}{*}{ Treatment } & \multicolumn{2}{|c|}{ Mycorrhizal colonization (\%) } & \multicolumn{2}{|c|}{$\mathrm{P}$ accumulation (g/seedling) } \\
\hline & A. chinensis & P. pinnata & A. chinensis & P. pinnata \\
\hline MOLOCO & $0.00 \pm 0.00 f$ & $0.00 \pm 0.00 f$ & $0.07 \pm 0.05 i$ & $0.98 \pm 0.14 \mathrm{e}$ \\
\hline MoL1C0 & $0.00 \pm 0.00 f$ & $0.00 \pm 0.00 f$ & $0.25 \pm 0.07 \mathrm{fghi}$ & $1.62 \pm 0.67 \mathrm{~cd}$ \\
\hline MOL0C1 & $0.00 \pm 0.00 f$ & $0.00 \pm 0.00 f$ & $0.40 \pm 0.03 \mathrm{efg}$ & $1.44 \pm 0.32 \mathrm{de}$ \\
\hline MoL1C1 & $0.00 \pm 0.00 f$ & $0.00 \pm 0.00 f$ & $0.42 \pm 0.09 \mathrm{def}$ & $1.57 \pm 0.49 d$ \\
\hline M1L0C0 & $8.00 \pm 3.74 \mathrm{e}$ & $6.00 \pm 2.45 \mathrm{de}$ & $0.16 \pm 0.06 \mathrm{hi}$ & $1.60 \pm 0.29 \mathrm{~cd}$ \\
\hline M1L1C0 & $36.00 \pm 9.27 \mathrm{~cd}$ & $12.00 \pm 7.35 \mathrm{cde}$ & $0.30 \pm 0.06 f g h$ & $1.62 \pm 0.29 \mathrm{~cd}$ \\
\hline M1L0C1 & $50.00 \pm 14.83 b c$ & $26.00 \pm 6.78 \mathrm{bcd}$ & $0.50 \pm 0.27 \mathrm{de}$ & $2.14 \pm 0.25 b c$ \\
\hline M1L1C1 & $80.00 \pm 7.07 a$ & $22.00 \pm 5.83 \mathrm{cde}$ & $0.59 \pm 0.12 \mathrm{~cd}$ & $2.59 \pm 0.33 a b$ \\
\hline M2LOCO & $8.00 \pm 2.00 e$ & $18.00 \pm 4.90 \mathrm{cde}$ & $0.21 \pm 0.02 \mathrm{ghi}$ & $1.57 \pm 0.04 d$ \\
\hline M2L1C0 & $36.00 \pm 13.64 \mathrm{~cd}$ & $12.00 \pm 2.00 \mathrm{cde}$ & $0.32 \pm 0.02$ efgh & $1.64 \pm 0.46 \mathrm{~cd}$ \\
\hline M2LoC1 & $14.00 \pm 6.78 \mathrm{de}$ & $28.00 \pm 7.35 a b c d$ & $0.78 \pm 0.13 b$ & $1.99 \pm 0.20 \mathrm{~cd}$ \\
\hline M2L1C1 & $66.00 \pm 9.80 a b$ & $44.00 \pm 9.27 a b$ & $1.01 \pm 0.25 a$ & $2.76 \pm 0.14 a$ \\
\hline M3L0C0 & $20.00 \pm 8.37 \mathrm{de}$ & $14.00 \pm 2.45 \mathrm{cde}$ & $0.37 \pm 0.06 \mathrm{efg}$ & $1.65 \pm 0.03 \mathrm{~cd}$ \\
\hline M3L1C0 & $78.00 \pm 9.70 a$ & $30.00 \pm 14.49 a b c$ & $0.79 \pm 0.14 b$ & $1.94 \pm 0.73 \mathrm{~cd}$ \\
\hline M3LOC1 & $56.00 \pm 8.12 a b c$ & $28.00 \pm 6.63 a b c d$ & $0.72 \pm 0.23 b c$ & $2.71 \pm 0.39 a$ \\
\hline M3L1C1 & $60.00 \pm 12.65 a b c$ & $48.00 \pm 9.70 a$ & $1.16 \pm 0.20 a$ & $2.86 \pm 0.35 a$ \\
\hline \multicolumn{5}{|l|}{ Significancy } \\
\hline$M$ & $* *$ & ** & $* \star$ & $* \star$ \\
\hline LC & $\star *$ & * & ** & $\star *$ \\
\hline$M \times L C$ & $\star \star$ & ns & $* *$ & * \\
\hline
\end{tabular}

M0, control; M1, MycoSilvi variant 1; M2, MycoSilvi variant 2; M3, MycoSilvi variant 3; L0, without lime; L1, lime 2.078 g; C0, without compost; $\mathrm{C} 1$, compost $20 \mathrm{~g}$. Each value is mean of five replicates \pm SD. Values in column followed by same letter are not significantly different $(\mathrm{P} \leq 0.5) .{ }^{* *}=\mathrm{P} \leq 0.01 ;{ }^{*}=0.01<\mathrm{P} \leq 0.05$ and $\mathrm{ns}=\mathrm{P}>0.05$.

The combination treatment of MycoSilvi and soil ameliorant significantly influences the rate of mycorrhizal colonization on $A$. chinensis seedling species, while for $P$. pinata was not significantly different. A. chinensis seedling inoculated with MycoSilvi variant 1 and amended with lime and compost produced the best results with an average mycorrhizal colonization rate of $80 \%$, while the best results of AM Fungi colonization in $P$. pinnata seedling was found in MycoSilvi variant 3 in combination with lime and compost with an average AM Fungi colonization rate of $48 \%$, indicating that there was synergetic effect between lime and compost on the improvement of AM Fungi colonization. The improvement of AM fungi colonization on soil media amended by lime and compost due to the increased of soil $\mathrm{pH}$ and decreased Aluminum content (data not presented). This result support previous reports (Jayani et al., 2018, Budi et al., 2020). The AM Fungi colonization rate in both plants species grown in medium without amended with lime or compost were lower than in other treatment because it contains high aluminum content and low $\mathrm{pH}$. This results in agreement with Agus et al. (2019) which stated that the rate of AM Fungi colonization of $P$. pinata was lower in mined-out soil medium than in forest soil medium, due to contamination by heavy metals in mined-out soil which may decreased soil $\mathrm{pH}$. Similar results were also reported by Budi et al. (2020) in Falcataria moluccana seedling.

\section{Role of AM Fungi on $P$ accumulation}

The lone factor of MycoSilvi inoculation and soil ameliorant addition and its interaction significantly influences the $\mathrm{P}$ accumulation of $A$. chinensis and P. pinnata seedlings (Table 1). A. chinensis inoculated with MycoSilvi variant 1, 2 and 3 increased $\mathrm{P}$ accumulation by $128.57 \%$, $200 \%$ and $428.5 \%$ respectively as compared to uninoculated plant, while in $P$. pinata seedling with the same treatment increased their $\mathrm{P}$ accumulation by $63.3 \%, 60.2 \%$ and $68.4 \%$ respectively as compared to uninoculated plant. Lime exhibited positive effect on $\mathrm{P}$ accumulation of $A$. chinensis and $P$. pinata with increased by $257 \%$ and $65.3 \%$ repectively, while compost contribute to $\mathrm{P}$ accumulation by $471.4 \%$ and $46.9 \%$ on $A$. chinensis and $P$. pinnata seedlings respectively. In general the combination treatments of MycoSilvi, lime and compost had higher $\mathrm{P}$ accumulation than others treatments. The combination treatment of MycoSilvi variant 3, lime and compost produced the best $\mathrm{P}$ accumulation in $A$. chinensis and $P$. pinata with increased by $1557 \%$ and $191.8 \%$ repectively as compared to uninoculated plant (Table 1). The increased of $\mathrm{P}$ accumulation on several leguminous mycorrhizal plants have been reported by several 
researchers (Maulana et al., 2017; Wulandari et al., 2016). It is well known that AM fungi plays an important role on increasing $\mathrm{P}$ uptake due to phosphatase enzyme production. According to Sato et al. (2015), the extraradical hyphae of AM fungi can release acid phosphatase enzyme in to the hyphosphere. These enzymes play an important role in mineralization fixed $\mathrm{P}$ into useful forms, which can be easily absorbed by plants roots (Rhicardson et al., 2009).

\section{Role of AM fungi on biomass and Chlorophyll content}

The study also showed that the interaction of MycoSilvi and soil ameliorant significantly increased total plant biomass and chlorophyll content as expressed by leaf greenness index on A. chinensis except on biomass of $P$. pinnata is not significantly different (Table 2). Total biomass of A. chinensis and $P$. pinnata inoculated by MycoSilvi variant 1,2 and 3 increased significantly by $180 \%$, $310 \%$ and $440 \%$ respectively for $A$. chinensis and $43.35 \%, 57.51 \%$ and $77.68 \%$ respectively for $P$. pinnata compared to un inoculated plant. While the total chlorophyll content of $A$. chinensis increased by $117.19 \%, 146.61 \%$ and $227.15 \%$ respectively and in P. pinnata increased by $14.29 \%, 24.01 \%$ and $26.49 \%$ respectively compared to un inoculated plant. According to Percival et al. (2008), leaf greenness index is a good indicator for $\mathrm{N}$, carotenoid and leaf chlorophyll content. Similar results have been reported by Arumugam et al. (2010) on Vigna unguiculata and by Sharma et al. (2017) on Vigna mungo due to increased phosphatase activity in plant inoculated by AMF. Since the chlorophyll plays an essential role for plant photosynthesis, increased chlorophyll content in the leaf cause increase in plant biomass (Table 2).

\section{Correlation between AM Fungi colonization and $P$ acumulation and Chlorophyl content}

Positive correlation between AM Fungi colonization rate and biomass $\mathrm{P}$ accumulation were observed for $A$. chinensis $\left(\mathrm{R}^{2}=0.3181, \mathrm{P}<001\right)$, and $P$. pinata $\left(\mathrm{R}^{2}=0.3152, \mathrm{P}<001\right)$ (Figure $1 \&$ Figure $2)$. This result exhibited that the increase of $P$ absorption could be related to the degree of AM fungi colonization. This data is in agreement with previous reports (Fini \& Ferrini, 2011; Mirkalaei et al., 2013; El-Kinany et al., 2019). According to Furtini-Neto et al. (2004), liming reduced the fixation of $\mathrm{P}$ by $\mathrm{Al}$ and $\mathrm{Fe}$, stimulated roots growth and finally increased nutrient uptake by plant roots. Our study also confirms the previous reports on Albizia saman and Mollatus paniculatus (Dewi et al., 2014), Paraserianthes falcataria and A. saman (Dewi et al., 2016) and in four legunimous trees;

Table 2. Effect of MycoSilvi and soil ameliorant on biomass and total chlorophyll content expressed by leaf greenness index of $A$. chinensis and $P$. pinnata (12 weeks after planting)

\begin{tabular}{|c|c|c|c|c|}
\hline \multirow{2}{*}{ Treatment } & \multicolumn{2}{|c|}{ Total Biomass (g) } & \multicolumn{2}{|c|}{ Leaf Greenness Index SPAD } \\
\hline & A. chinensis & P. pinnata & A. chinensis & P. pinnata \\
\hline MOLOCO & $0.20 \pm 0.14 f$ & $2.33 \pm 0.34 \mathrm{~g}$ & $4.42 \pm 1.09 \mathrm{~g}$ & $31.07 \pm 1.21 \mathrm{~h}$ \\
\hline MOL1C0 & $0.65 \pm 0.18 \mathrm{ef}$ & $3.45 \pm 1.42 \mathrm{fg}$ & $11.35 \pm 1.41 f$ & $32.43 \pm 1.07 \mathrm{gh}$ \\
\hline MOL0C1 & $1.06 \pm 0.09 \mathrm{de}$ & $3.64 \pm 0.42 \mathrm{ef}$ & $14.40 \pm 1.32 \mathrm{e}$ & $34.13 \pm 1.01 \mathrm{fg}$ \\
\hline MoL1C1 & $1.12 \pm 0.23 \mathrm{de}$ & $4.25 \pm 1.33 f$ & $14.68 \pm 1.05 e$ & $33.97 \pm 0.57 \mathrm{fg}$ \\
\hline M1L0C0 & $0.56 \pm 0.20 \mathrm{ef}$ & $3.34 \pm 0.41 \mathrm{fg}$ & $9.60 \pm 0.46 f$ & $35.50 \pm 1.32 \mathrm{ef}$ \\
\hline M1L1C0 & $1.43 \pm 0.37 \mathrm{~cd}$ & $3.85 \pm 0.57 \mathrm{def}$ & $13.13 \pm 0.32 e$ & $38.33 \pm 1.76 \mathrm{~cd}$ \\
\hline M1L0C1 & $1.47 \pm 0.79 c d$ & $4.32 \pm 0.37 b c d e f$ & $17.83 \pm 1.48 \mathrm{~cd}$ & $37.00 \pm 0.46 \mathrm{de}$ \\
\hline M1L1C1 & $2.36 \pm 0.47 a b$ & $5.40 \pm 0.68 \mathrm{abc}$ & $19.83 \pm 1.15 a b$ & $44.90 \pm 0.46 a$ \\
\hline M2LOCO & $0.82 \pm 0.06 \mathrm{e}$ & $3.67 \pm 0.42 \mathrm{ef}$ & $10.90 \pm 1.03 f$ & $38.53 \pm 1.56 \mathrm{~cd}$ \\
\hline M2L1C0 & $1.70 \pm 0.10 c$ & $3.92 \pm 1.10 \mathrm{def}$ & $16.97 \pm 0.46 d$ & $39.17 \pm 1.76 c$ \\
\hline M2LoC1 & $1.97 \pm 0.33 \mathrm{bc}$ & $4.74 \pm 0.47 a b c d e$ & $18.53 \pm 0.90 \mathrm{bcd}$ & $41.97 \pm 1.32 b$ \\
\hline M2L1C1 & $2.60 \pm 0.63 a$ & $5.51 \pm 0.28 a b$ & $20.70 \pm 1.38 a$ & $46.00 \pm 1.11 \mathrm{a}$ \\
\hline M3L0CO & $1.08 \pm 0.16 \mathrm{de}$ & $4.14 \pm 0.05 \mathrm{def}$ & $16.67 \pm 0.60 d$ & $39.30 \pm 0.96 c$ \\
\hline M3L1C0 & $2.59 \pm 0.46 a$ & $4.32 \pm 1.63 b c d e f$ & $17.93 \pm 0.40 \mathrm{bcd}$ & $40.00 \pm 0.61 c$ \\
\hline M3L0C1 & $2.38 \pm 0.75 a b$ & $5.02 \pm 0.72 \mathrm{abcd}$ & $19.40 \pm 1.13 b c$ & $42.63 \pm 0.64 b$ \\
\hline M3L1C1 & $2.82 \pm 0.48 a$ & $5.71 \pm 0.82 a$ & $21.20 \pm 1.00 a$ & $46.33 \pm 0.76 a$ \\
\hline \multicolumn{5}{|l|}{ Significancy } \\
\hline$M$ & ** & ** & ** & ** \\
\hline LC & ** & $* *$ & $\star \star \star \star *$ & \\
\hline$M \times L C$ & * & ns & $* *$ & $\star \star *$ \\
\hline
\end{tabular}

M0, control; M1, MycoSilvi variant 1; M2, MycoSilvi variant 2; M3, MycoSilvi variant 3; L0, without lime; L1, lime 2.078 g; C0, without compost; $\mathrm{C} 1$, compost $20 \mathrm{~g}$. Each value is mean of five replicates $\pm \mathrm{SD}$. Values in column followed by same letter are not significantly different $(\mathrm{P} \leq 0.5) .{ }^{* *}=\mathrm{P} \leq 0.01 ;{ }^{*}=0.01<\mathrm{P} \leq 0.05$ and $\mathrm{ns}=\mathrm{P}>0.05$. 


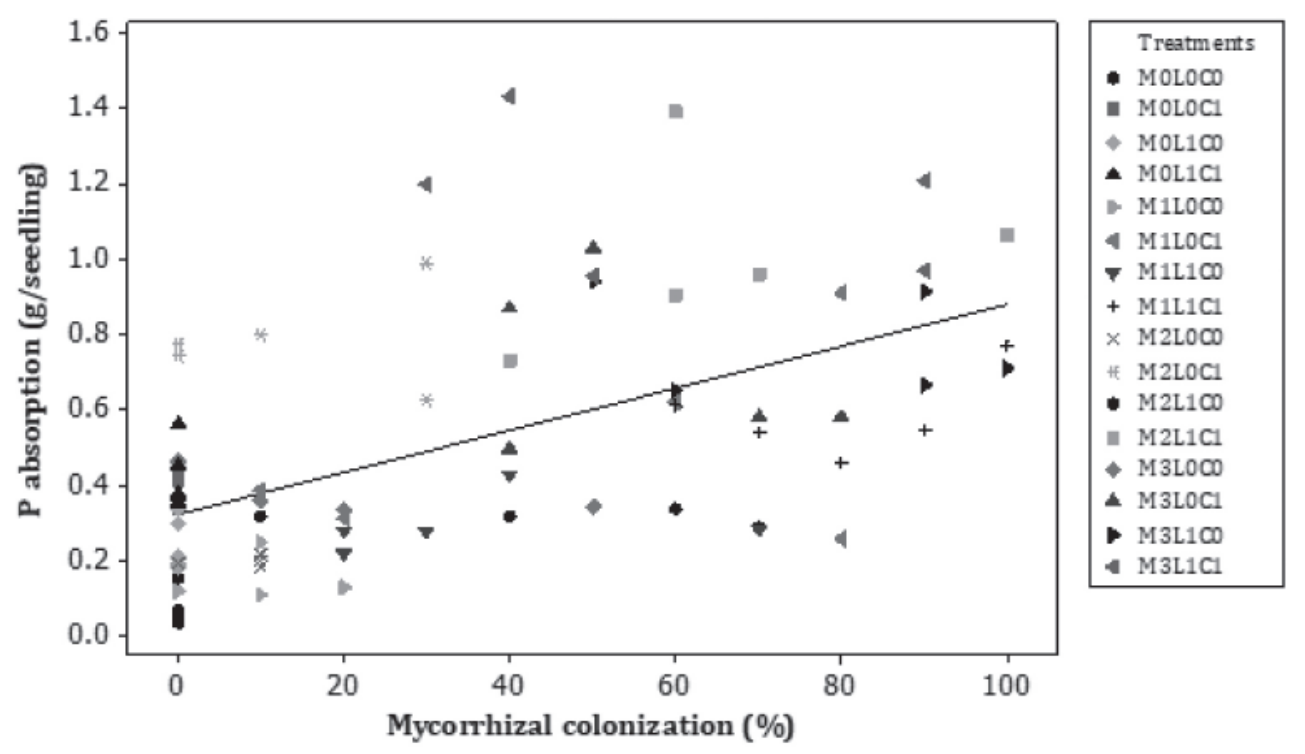

$\mathrm{P}$ absorption ( $\mathrm{g} /$ seedling $)=0.0056 \mathrm{Mycorrhizal} \mathrm{colonization}(\%)+0.3237$ $\mathrm{R}^{2}=0.3181$

Fig. 1. Correlation between AM Fungi colonization rate and $\mathrm{P}$ accumulation of $A$. chinensis.

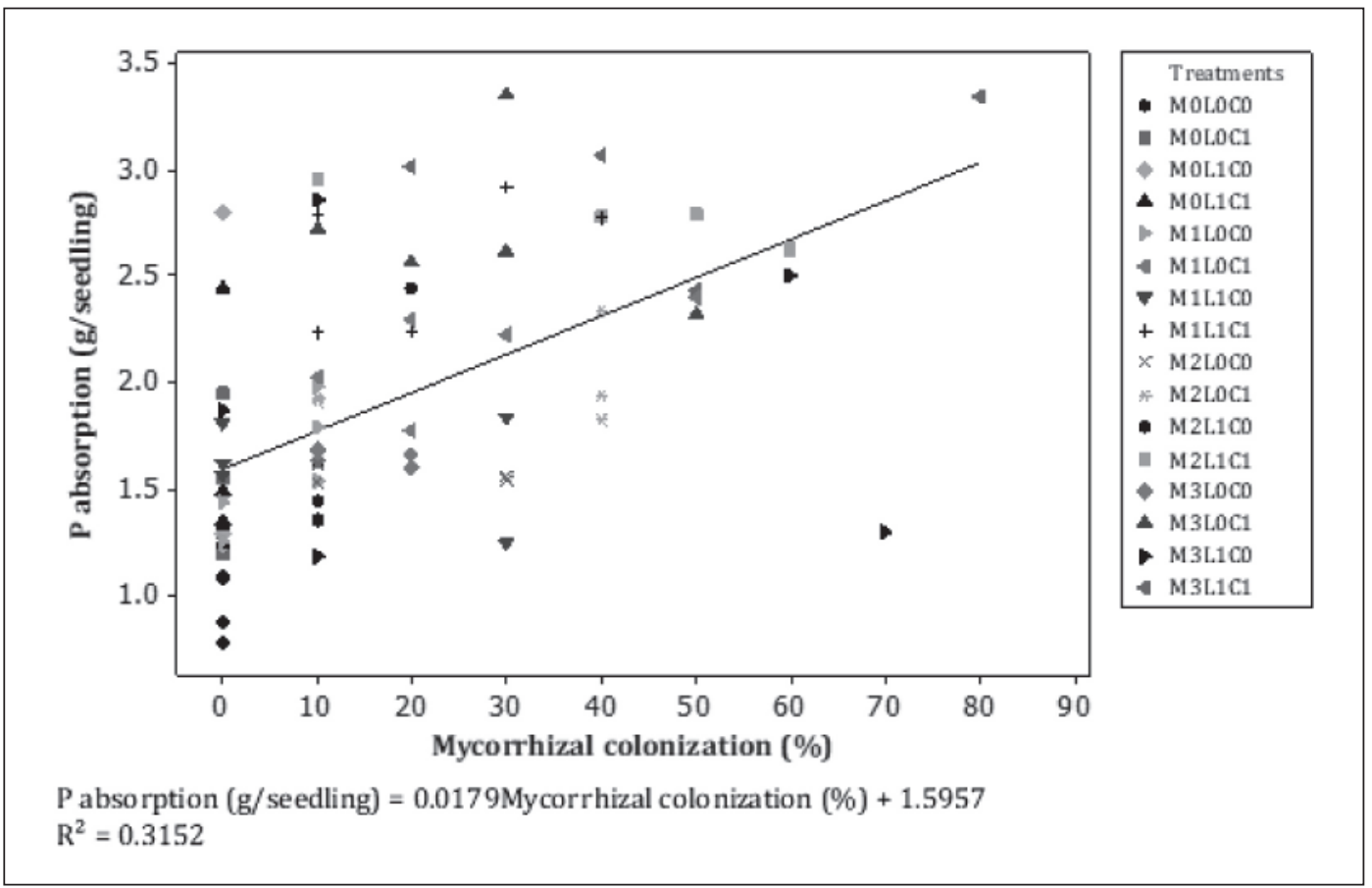

Fig. 2. Correlation between AM Fungi colonization rate and $\mathrm{P}$ accumulation of $P$. pinata.

P. falcataria, Calliandra caothyrsus, Cassia siamea and Sesbania grandiflora (Maulana et al., 2017), which sated the positive correlation between mycorrhizal roots colonization and $\mathrm{P}$ accumulation. AM Fungi colonization also positively correlated with chlorophyll content of $A$. chinensis $\left(\mathrm{R}^{2}=0.413\right.$, $\mathrm{P}<001)$, and $P$. pinata $\left(\mathrm{R}^{2}=0.3885, \mathrm{P}<001\right)$ (Figure
3 \& Figure 4). According to Zhu et al. (2014), the increase in chlorophyll content in mycorrhizal plant is related to the increase in absorption of $\mathrm{P}$ and $\mathrm{Mg}$ from the soil. This support our data, which demonstrate that $\mathrm{P}$ absorption is positively correlated with AM Fungi colonization. 


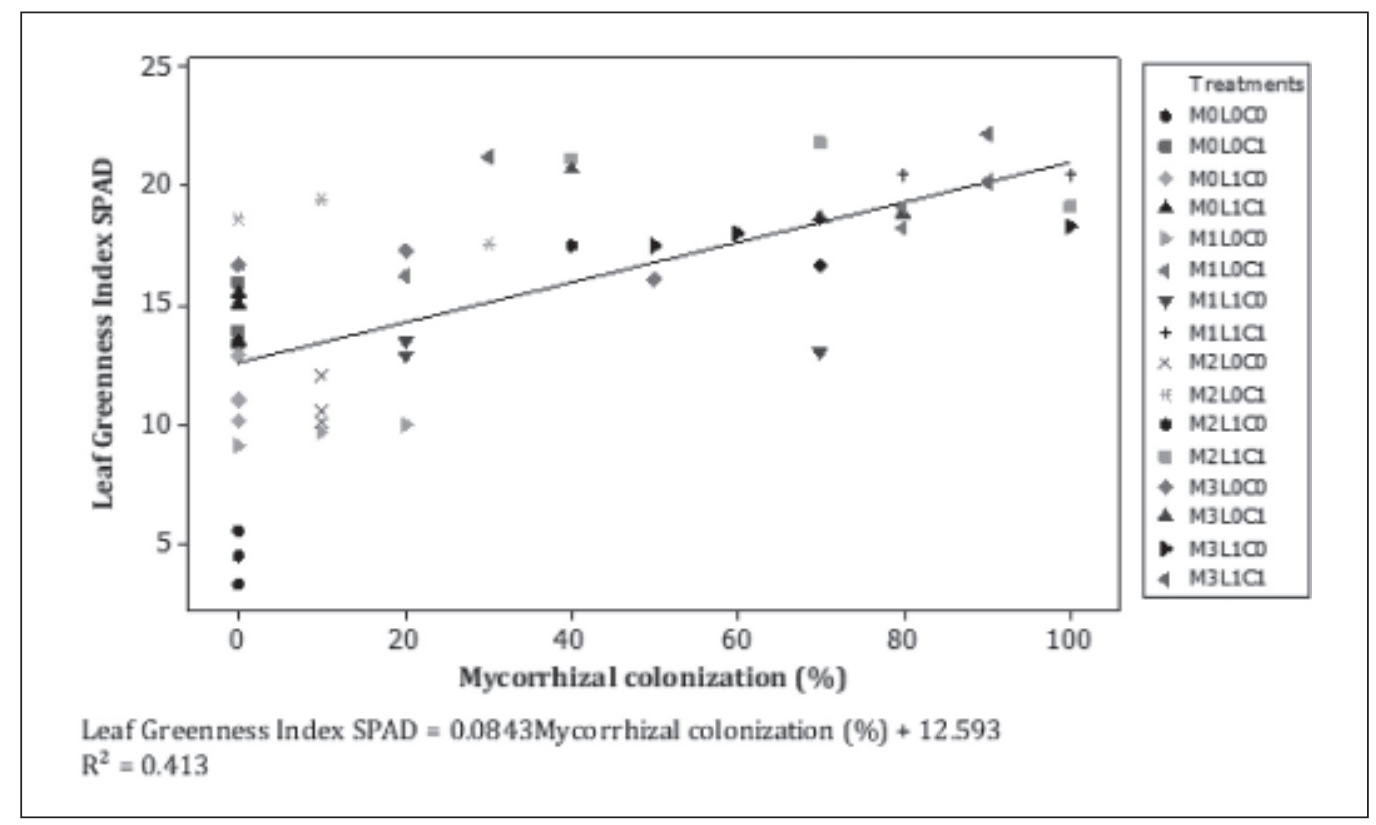

Fig. 3. Correlation between AM Fungi colonization rate and Chlorophyl content of $A$. chinensis.

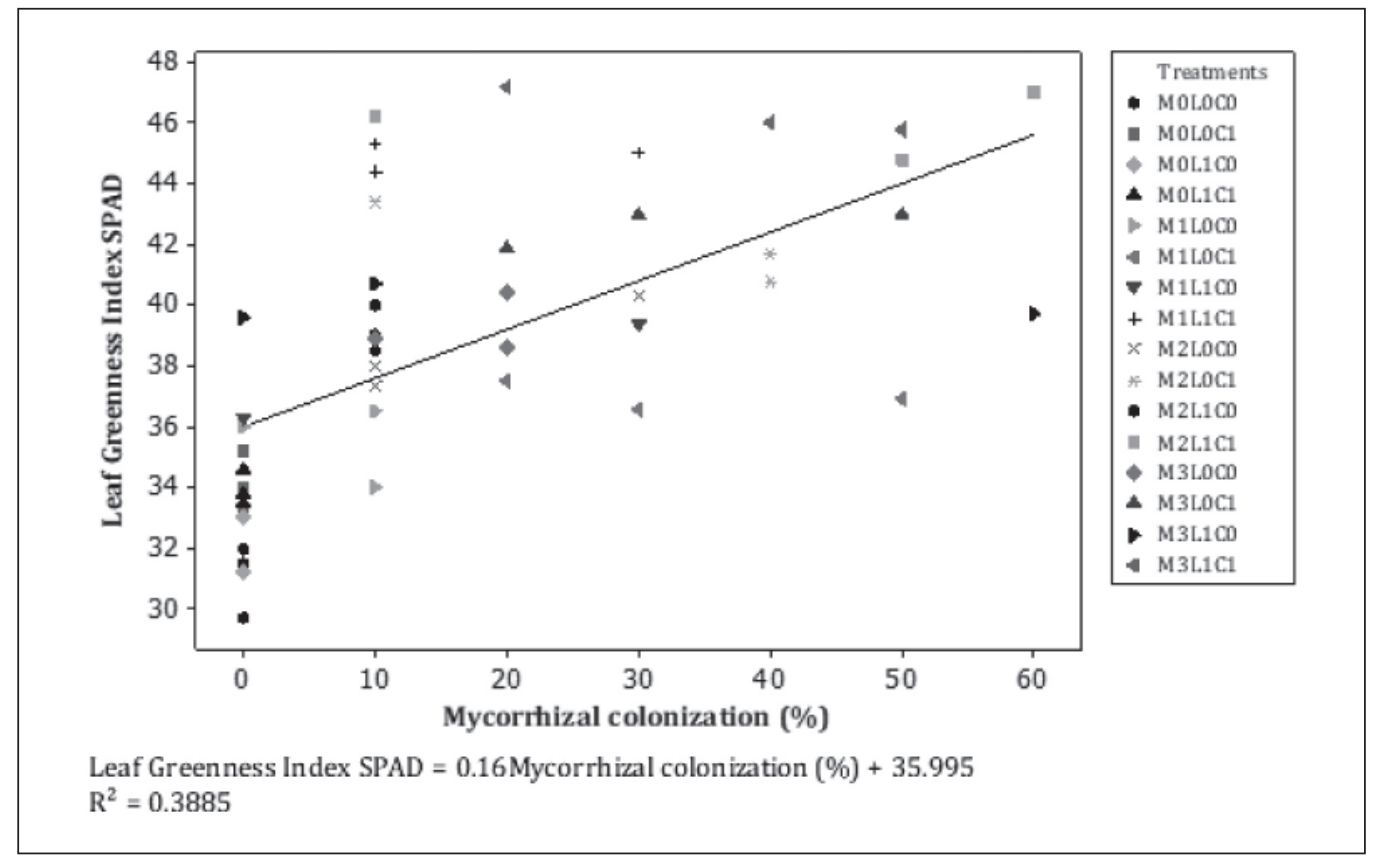

Fig. 4. Correlation between AM Fungi colonization rate and Chlorophyl content of $P$. pinata.

\section{Role of AM Fungi on plant growth}

Data for seedling height and steam diameter growth is presented in Table 3. There was a significant interaction between MycoSilvi inoculation treatment and soil ameliorant addition to the soil media $(\mathrm{p}<0.05)$ for $A$. chinensis while for $P$. pinnata there was no significant difference. A. chinensis inoculated by MycoSilvi variant 1,2 and 3 significantly increased height growth by $185.7 \%, 210 \%$ and $248.57 \%$ respectively and steam diameter growth by $362.96 \%, 401.85 \%$ and $520.37 \%$ respectively compared to control plants. Plant height and diameter of $A$. chinensis inoculated by three MycoSilvi variants was not significantly different. The addition of lime to soil media increased significantly height and steam diameter growth of A. chinensis by $415.71 \%$ and $668.52 \%$ respectively compared to the control, and higher than those plant inoculated by MycoSilvi alone. Interactions of lime and MycoSilvi significantly 
Table 3. Effect of MycoSilvi and soil ameliorant on height and steam diameter of $A$. chinensis and $P$. pinnata (12 weeks after planting)

\begin{tabular}{|c|c|c|c|c|}
\hline \multirow{2}{*}{ Treatment } & \multicolumn{2}{|c|}{ Height growth $(\mathrm{cm})$} & \multicolumn{2}{|c|}{ Steam diameter growth $(\mathrm{mm})$} \\
\hline & A. chinensis & P. pinnata & A. chinensis & P. pinnata \\
\hline MOLOCO & $1.40 \pm 0.96 \mathrm{e}$ & $3.36 \pm 1.07 f$ & $0.11 \pm 0.08 i$ & $1.02 \pm 0.22 f$ \\
\hline MoL1C0 & $7.22 \pm 1.51 \mathrm{c}$ & $9.10 \pm 2.30 \mathrm{de}$ & $0.84 \pm 0.07$ defg & $1.54 \pm 0.48 \mathrm{cdef}$ \\
\hline MOL0C1 & $10.12 \pm 0.28 b$ & $9.86 \pm 2.12 \mathrm{cde}$ & $0.77 \pm 0.18$ efgh & $1.91 \pm 0.61 \mathrm{abcd}$ \\
\hline MoL1C1 & $10.76 \pm 0.38 b$ & $10.48 \pm 1.71 \mathrm{bcd}$ & $0.98 \pm 0.24 b c d e$ & $1.65 \pm 0.57 \mathrm{bcde}$ \\
\hline M1L0C0 & $4.00 \pm 1.80 \mathrm{~d}$ & $5.56 \pm 2.87 \mathrm{ef}$ & $0.50 \pm 0.04 h$ & $1.10 \pm 0.38 f$ \\
\hline M1L1C0 & $10.32 \pm 1.51 b$ & $13.78 \pm 3.71 \mathrm{abc}$ & $1.13 \pm 0.33 a b c d$ & $1.68 \pm 0.33 \mathrm{bcde}$ \\
\hline M1L0C1 & $10.32 \pm 2.38 b$ & $11.34 \pm 3.88 \mathrm{bcd}$ & $0.84 \pm 0.38 \mathrm{defg}$ & $1.83 \pm 0.32 \mathrm{de}$ \\
\hline M1L1C1 & $14.68 \pm 4.25 a$ & $14.00 \pm 3.506 a b c$ & $1.25 \pm 0.41 a b$ & $1.88 \pm 0.25 a b c$ \\
\hline M2LOCO & $4.34 \pm 0.74 d$ & $8.42 \pm 3.25 \mathrm{de}$ & $0.54 \pm 0.05 \mathrm{gh}$ & $1.33 \pm 0.23 \mathrm{abcd}$ \\
\hline M2L1C0 & $10.82 \pm 0.28 b$ & $14.66 \pm 1.52 \mathrm{ab}$ & $1.17 \pm 0.04 a b c$ & $1.81 \pm 0.35 \mathrm{ef}$ \\
\hline M2L0C1 & $10.72 \pm 1.64 b$ & $11.48 \pm 4.06 \mathrm{bcd}$ & $0.93 \pm 0.29 \mathrm{cdef}$ & $2.07 \pm 0.09 a b c$ \\
\hline M2L1C1 & $15.92 \pm 0.49 a$ & $14.86 \pm 3.29 a b$ & $1.28 \pm 0.20 a b$ & $1.91 \pm 0.45 \mathrm{abcd}$ \\
\hline M3L0C0 & $4.88 \pm 0.50 \mathrm{~d}$ & $8.58 \pm 2.45 \mathrm{de}$ & $0.67 \pm 0.11 \mathrm{fgh}$ & $1.37 \pm 0.14 \mathrm{def}$ \\
\hline M3L1C0 & $15.28 \pm 2.44 a$ & $16.34 \pm 3.16 a$ & $1.21 \pm 0.24 a b c$ & $1.90 \pm 0.22 \mathrm{abcd}$ \\
\hline M3L0C1 & $10.90 \pm 1.36 b$ & $13.92 \pm 1.58 \mathrm{abc}$ & $0.98 \pm 0.10 \mathrm{bcde}$ & $2.11 \pm 0.24 a b$ \\
\hline M3L1C1 & $16.68 \pm 1.68 a$ & $17.06 \pm 3.08 a$ & $1.36 \pm 0.14 a$ & $2.28 \pm 0.44 a$ \\
\hline \multicolumn{5}{|l|}{ Significancy } \\
\hline M & ** & ** & $\star *$ & * \\
\hline LC & ** & $\star \star$ & ** & ** \\
\hline$M \times L C$ & * & ns & * & ns \\
\hline
\end{tabular}

M0, control; M1, MycoSilvi variant 1; M2, MycoSilvi variant 2; M3, MycoSilvi variant 3; L0, without lime; L1, lime 2.078 g; C0, without compost; $\mathrm{C} 1$, compost $20 \mathrm{~g}$. Each value is mean of five replicates \pm SD. Values in column followed by same letter are not significantly different $(\mathrm{P} \leq 0.5) .{ }^{* *}=\mathrm{P} \leq 0.01 ;{ }^{*}=0.01<\mathrm{P} \leq 0.05$ and $\mathrm{ns}=\mathrm{P}>0.05$

increased height and steam diameter growth of A. chinensis. Combination treatment lime and MycoSilvi variant 1, 2 and 3 increased height growth of $A$. chinensis by $637.34 \%, 672.86 \%$ and $991.43 \%$ respectively and steam diameter growth by $944.44 \%, 985 \%$ and $1020.37 \%$ respectively compared to control plant. These results demonstrated that there was synergetic effect between MycoSilvi and lime for improving plant growth, while MycoSilvi variant 3 gave the best results.

The addition of compost to soil media increased height and steam diameter growth significantly of A. chinensis by $622.86 \%$ and $614.81 \%$ compared to control plant and higher than plant inoculated by MycoSilvi alone or soil media added by lime. There is no significant difference on the interaction of compost and Mycosilvi to the plant height and steam diameter growth, even though the combination of compost and Mycosilvi variant 1, 2, 3 increased plant height and steam diameter. Similar to this result, treatment with compost alone also gave no significant difference, indicating there is no synergetic effect between compost and MycoSilvi. Nevertheless, synergetic effect was obtained when compost, lime and MycoSilvi were combined. The MycoSilvi inoculation significantly influenced the growth of $P$. pinnata seedlings (Table 3 ). $P$. pinnata inoculated by MycoSilvi variant 1, 2 and 3 increased height by $65.48 \%, 150.60 \%$ and $155.36 \%$ respectively and steam diameter growth by $7.84 \%$, $30.39 \%$ and $34.31 \%$ respectively compared to control plant. $P$. pinnata treated with MycoSilvi and soil ameliorant gave similar resulta as $A$. chinensis. Synergetic effect was observed when compost, lime and MycoSilvi were combined.

Previous study demonstrated that soil ameliorant could improve acid soil properties and plant growth (Teshome et al., 2017). Our results demonstrate that the addition of lime and compost increased soil $\mathrm{pH}$ and decreased Al-dd in soil medium (data not presented). Plant growth is influenced by genetic and environmental factor such as sunlight, water and nutrients both macro and micro. In nature, the presence of sunlight and water is very abundant, but the presence of nutrients is often become limiting factor for plant growth, especially in acidic soil and in post mining soil. In this study, post-mining soil used as growing media categorized as very low-fertility soil. The chemical characteristics of these soil are; $\mathrm{pH} 3.20, \mathrm{C}$-organic $4.21 \%, \mathrm{P}$ available $13.78 \mathrm{ppm}$ and total $\mathrm{P} 278.04$ ppm and Al $690 \mathrm{mg} / \mathrm{kg}$. The low pH and high aluminum content in these soil growing media become limiting factors for plant growth. In this study, the growth of $A$. chinensis and $P$. pinnata are very poor in control treatment. Incoulation of MycoSilvi to the plant resulted in increasing plant height and steam diameter of $A$. chinensis and $P$. pinnata (Table 3). MycoSilvi is a biological 
fertilizer product containing arbuscular mycorrhizal fungi. Those fungi is widely used as natural biofertilizers (Berruti et al., 2016) due to their contribution to alleviate water stress (Sharma et al., 2017), and aluminium stress (Alori \& Fawole, 2012), prevent nutrient loss from the soil (Kohl \& van der Heijden, 2016) increasing phosphate uptake (Hart \& Forsythe, 2012), increasing nitrogen uptake (Bucking \& Kafle, 2015), improve soil chemical properties (Pal \& Pandey, 2017) and improve soil agregation (Borie et al., 2008). The use of lime in acidic soil to reduced Al toxicity were well documented (Muindi et al., 2015; Teshome et al., 2017). In this study, the application of lime increased height and steam diameter growth significantly in both plants (Table 3 ), increased soil $\mathrm{pH}$ and reduced Aluminium content (data not shown). This result confirms the study by Bambara and Ndakidemi (2009), showing that lime increased the rate of photosynthesis in Phaseolus vulgaris L. Our finding suggests that the combination of lime and MycoSilvi synergistically increase height and steam diameter growth of both plant trees species. Our results are contrary to Guo et al. (2010), who found that there was no synergetic effect when lime and AMF applied in acid purplish soil. This is due to different chemical soil properties used. In our study the $\mathrm{pH} \mathrm{H}_{2} \mathrm{O}$ of soil media was 3.20; P (Bray I) $=13.78 ; \mathrm{P}(\mathrm{HCl} 25 \%)=278.04$ ppm and Al-dd = $690 \mathrm{mg} / \mathrm{kg}$ while Guo et al. (2010) used soil media with low Aluminum content $(0.7 \mathrm{mg} / \mathrm{kg})$ and $\mathrm{pH} 5.45$, and after lime treatment, the $\mathrm{pH}$ increased to 6.45 . Probably by increasing soil $\mathrm{pH}$, the soluble soil $\mathrm{P}$ would be quite high which may inhibit mycorrhizal colonization and plant growth. According to Amijee et al. (1989), the soluble soil P 140 ppm inhibited mycorrhizal colonization, while in our study the addition of lime increased soluble soil $\mathrm{P}$ between 1.56-3.27 ppm (data not presented). In acidic soil, Phosphorus is bound by Aluminum and cannot be absorbed by the roots of the plant. With the addition of MycoSilvi, ion phosphate can be released through an enzymatic phosphatase process which is released by the AMF (Sharma et al., 2017). Furthermore, according to Jung et al. (2003), mycorrhizal plant can decrease heavy metals content by organic acids which exudates by plant roots. The application of lime aims to increase soil $\mathrm{pH}$ and liberate soil Phosphorous which is bound by aluminum, thus becomes available and can be absorbed by the roots of the plant.

The positive effects of compost amendment on degraded soil are well known. Our study demonstrated that acidic soil amended with compost increased significantly height and steam diameter growth of $A$. chinensis and $P$. pinnata (Table 3 ). This data is in accord with Mirkalaei et al. (2013) and Mrabet et al. (2014), describing significant plant growth upon addition of compos to soil media. However, the combination of compost and MycoSilvi had only slight additive effect on height and steam diameter growth of both plant which is in agreement with previous reports (Mrabet et al., 2014). Meanwhile, when three treatments were combined, synergetic effect was determined. $A$. chinensis inoculated by MycoSilvi variant 1, 2 and 3 grown in soil media incorporated by compost and lime significantly increase height growth by $948.57 \%, 1037.14 \%$ and $1091.43 \%$ respectively and steam diameter growth by $1057.41 \%, 1085.19 \%$ and $1159.26 \%$ respectively as compared to control plant and $P$. pinnata inoculated by MycoSilvi variant 1, 2 and 3 grown in soil media incorporated with compost and lime increase height growth by $316.67 \%, 342.26 \%$ and $407.74 \%$ respectively, and steam diameter growth by $84.31 \%, 87.25 \%$ and $123.53 \%$ respectively as compared to control. Indicating that the role of AMF and lime is very important. It also important to note that the combination of MycoSilvi variant 3, lime and compost gave the best results for improving height and steam diameter growth of $A$. chinensis and $P$. pinnata. This due to the number of AMF species in MycoSilvi variant 3 higher than in MycoSilvi variant 1 and 2 . These results were in agreement with the previous finding that Cucumber seedling inoculated with combination of five and three AMF species had better growth than inoculated by single species (Chen et al., 2017). Similar results also reported by Kohl and van der Heijden (2016) that AMF variantied in their effects on plant nutrient acquisition and growth, and Budi et al. (2020), stated that MycoSilvi varaint 3 gave the best result on $F$. moluccana growth. In addition MycoSilvi variant 3 gave the best in the improvement on $P$ accumulation and chlorophyll content of both two tropical tree species which have been discussed previously. The growth performance of $A$. chinensis and $P$. pinata presented in Figure 5 and Figure 6.

\section{CONCLUSION}

MycoSilvi inoculation colonized the roots of $A$. chinensis and $P$. pinnata and positively correlated with $\mathrm{P}$ accumulation and leaf greenness index of both plant species. MycoSilvi variant 2 which contained two AMF species gave the best mycorrhizal roots colonization (18\%) in A. chinensis while MycoSilvi variant 3 which contain three AMF species gave the best mycorrhizal roots colonization $(20 \%)$ in $P$. pinnata. The addition of lime and compost increased mycoorhizal roots colonization in both plant species. The best mycorrhizal roots 


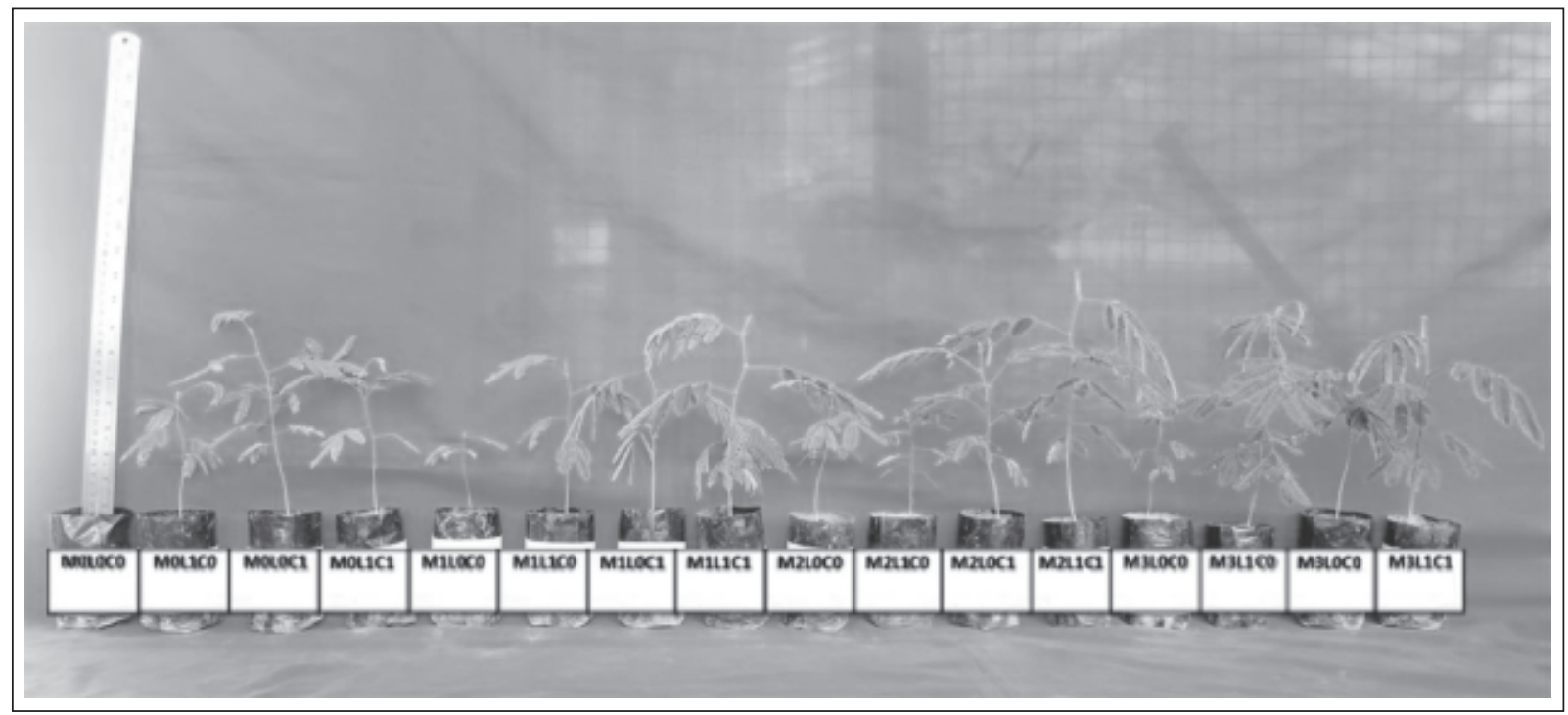

Fig. 5. Growth performance of $A$. chinensis as affected by MycoSilvi and soil ameliorant. M0=Without MycoSilvi; M1= MycoSilvi variant $1 ; \mathrm{M} 2=$ MycoSilvi variant 2; M3=MycoSilvi variant 3; L0= without lime; L1: with lime; C0= without compost; $\mathrm{C} 1$ = with compost.

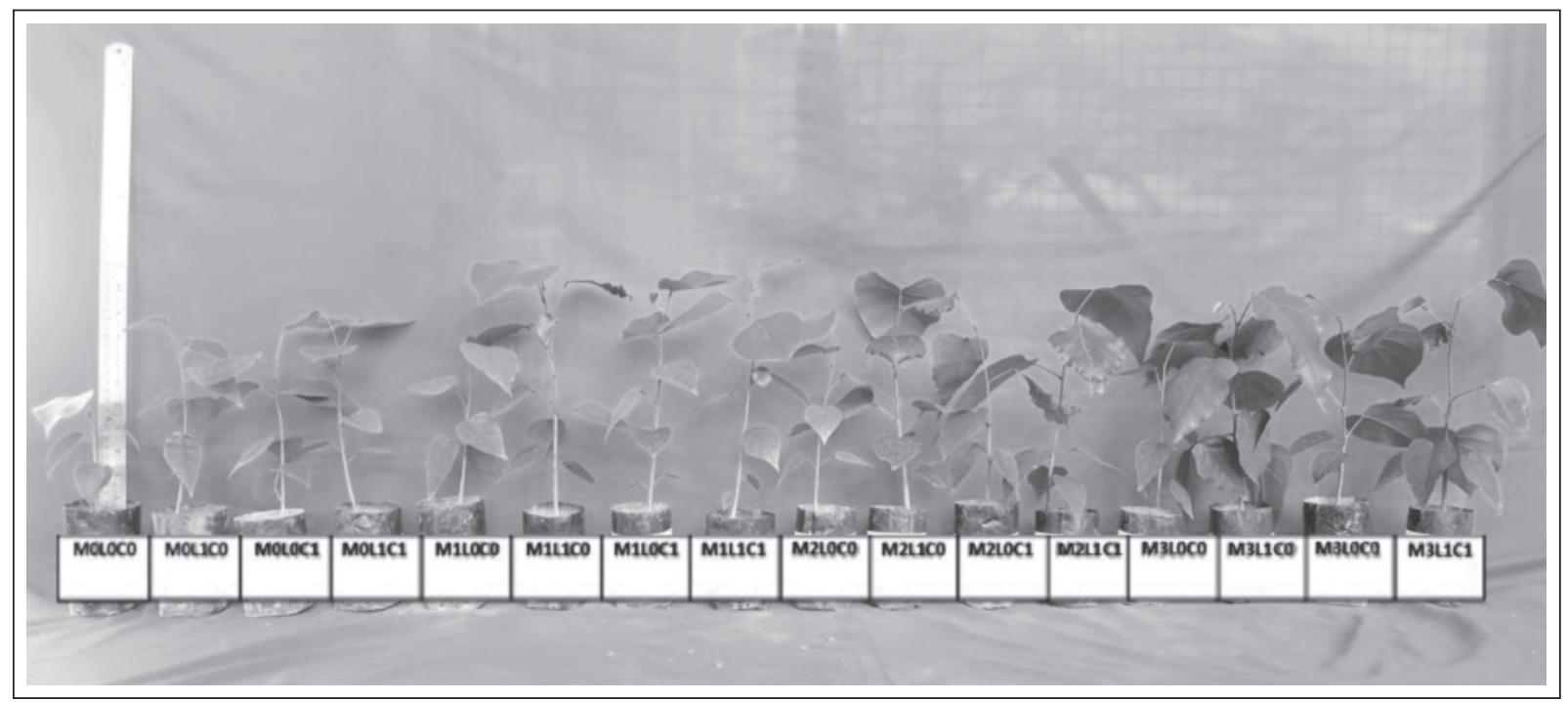

Fig. 6. Growth performance of $P$. pinata as affected by MycoSilvi and soil ameliorant. M0=Without MycoSilvi; M1= MycoSilvi variant 1 ; M2=MycoSilvi variant 2; M3=MycoSilvi variant 3; L0= without lime; L1: with lime; $\mathrm{C} 0=$ without compost; $\mathrm{C} 1$ = with compost.

colonization $(80 \%)$ obtained from the combination of lime and compost with MycoSilvi variant 1 in $A$. chinensis and the combination of lime and compost with MycoSilvi variant 3 in $P$. pinnata. The highest $P$ accumulation, leaf greenness index and total biomass growth were obtained from the combination of lime and compost with MycoSilvi variant 3, with the value of $1.6 \mathrm{~g} /$ seedling, 21.20 , and $2.82 \mathrm{~g}$ in A. chinensis respectively and $2.86 \mathrm{~g} /$ seedling, 46.33 and $5.71 \mathrm{~g}$ respectively in $P$. pinnata. The important findings of this research is that post mining soil with low $\mathrm{pH}$ and high Aluminium content could be improved for $A$. chinensis and $P$. pinnata plant growth by application of MycoSilvi, lime and compost alone or in combination. The positive effect of MycoSilvi or compost can be maximized by addition of lime. These findings imply the prospective and potential use of MycoSilvi and soil ameliorant for the succesful of post mine land rehabilitation. 


\section{ACKNOWLEDGEMENTS}

We are grateful to Directorate for Research and Community Services, Ministry of Research, Technology, and Higher Education, the Republic of Indonesia, for providing the grant in accordance to the Letter Agreement of Implementation Research Grant No. 1786/IT3.11/PN/2018 dated 21 February 2018. The authors also wish to thank to PT Holcim Indonesia Tbk., Sukabumi, West Java, for providing soil media for this research.

\section{REFERENCES}

Agus, C., Primananda, E., Faridah, E., Wulandari, D. \& Lestari, T. 2019. Role of arbuscular mycorrhizal fungi and Pongamia pinnata for revegetation of tropical open-pit coal mining soils. Int. Journal of Environmental Science and Technology, 16(7): 3365-3374.

Amudha, P., Prabakaran, R., Kumar, S.S. \& Gopinath, L.R. 2017. Phytochemical analysis of Albizia chinensis (Osbeck) Merr Medicinal Plant. IOSR Journal of Pharmacy and Biological Science, 12(6): 89-92.

Alori, E. \& Fawole, O. 2012. Phytoremediation of soils contaminated with aluminium and manganese by two arbuscular mycorrhizal fungi. Journal of Agricultural Science, 4(8): 246-252.

Amijee, F., Tinker, P.B. \& Stribley, D.P. 1989. The development of endomycorrhizal root systems. VII. A detailed study of effects of soil phosphorus on colonization. New Phytologist, 111: 435-446.

Anetor, M.O. \& Akinrinde, E.A. 2007. Lime effectiveness of some fertilizers in a tropical acid alfisol. Journal of Central Europeean Agriculture, 8(1): 17-24.

Arumugam, R., Rajasekaran, S. \& Nagarajan, S.M. 2010. Response of arbuscular mycorrhizal fungi and rhizobium inoculation on growth and chlorophyll content of Vigna unguiculata (L) Walp Var. Pusa 151. Journal of Applied Sciences and Environmental Management, 14(4): 113-115.

Asmelash, F., Bekele, T. \& Birhane, E. 2016. The Potential Role of Arbuscular Mycorrhizal Fungi in the Restoration of Degraded Lands. Frontiers in Microbiology, 7: 1095.

Bakhtiar, Y., Yahya, S., Sumaryono, W., Sinaga, M.S., Budi, S.W. \& Tajudin, T. 2010. Isolation and identification of mycorrhizosphere bacteria and their antagonistic effects towards Ganoderma boniense in vitro. Journal of Microbiology Indonesia, 4(2): 96-102.
Bambara, S. \& Ndakidemi, P.A. 2009. Effect of rhizobium inoculation, lime and molybdenum on photosynthesis and chlorophyll content of Phaseolus vulgaris L. African Journal of Microbiology Research, 3(11): 791-798.

Bationo, A., Hartemink, A., Lungu, O., Naimi, M., Okoth, P., Sambling, E. \& Thiombano, L. 2006. African soils: their productivity and profitability for use. Paper presented at the African Fertiliser Summit, Abuja (Nigeria).

Baum, C., El-Tohamy, W. \& Gruda, N. 2015. Increasing the productivity and product quality of vegetable crops using arbuscular mycorrhizal fungi: A review. Scientia Horticulturae, 187: 131-141.

Bekele, A., Kibret, K., Bedadi, B., Yli-Halla, M.J. \& Balemi, T. 2018. Effects of Lime, Vermicompost, and Chemical P Fertilizer on Selected Properties of Acid Soils of Ebantu District, Western Highlands of Ethiopia.

Berruti, A., Lumini, E., Balestrini, R. \& Bianciotto, V. 2016. Arbuscular mycorrhizal fungi as natural biofertilizers: Let's benefit from past successes. Frontiers in Microbiology, 6: 1559.

Bhalerao, S.A. \& Sharma, A.S. 2014. Etnopharmacology, phytochemistry and pharmacological evaluation of Pongomia pinnata (L) Pierre. International Journal of Current Reseach in Biosciences and Plant Biology, 1(3): 50-60.

Bini, D., Alcara, dos, Santos, C., da, Silva, M.C.P., Bonfirm, J.A. \& Cardoso, E.J.B.N. 2017. Intercropping Acacia mangium stimulates AMF colonization and soil phosphatase activity in Eucalyptus grandis. Scientia Agricola, 2(2): 102-110.

Borie, F., Rubio, R. \& Morales, A. 2008. Arbuscular mycorrhizal fungi and soil aggregation. Journal Soil Plant Nutrition, 8(2): 9-18.

Bucking, H. \& Kafle, A. 2015. Role of arbuscular fungi in the nitrogen uptake of plants: current knowledge and research gaps. Agronomy, 5: 587-612.

Budi, S.W. \& Christina, F. 2013. Coal waste powder amendment and arbuscular mycorrhizal fungi enhance the growth of jabon (Anthocephalus cadamba Miq) seedling in ultisol soil medium. Journal Tropica Soils, 18: 59-66.

Budi, S.W. \& Setyaningsih, L. 2013. Arbuscular mycorrhizal fungi and biochar improved early growth of neem (Melia azedarach Linn.) seedling under greenhouse conditions. Jurnal Manajenen Hutan Tropika, 19(2): 103-110.

Budi, S.W. \& Dewi A.P. 2016. Diversity of arbuscular mycorrhizal fungi under Jabon (Anthocephalus cadamba) plantation, Madiun, East Java. Jurnal Silvikultur Tropika, 7(2): 146-152. 
Budi, S.W., Wibowo, C., Sukendro, A. \& Bekti, H.S. 2020. Growth improvement of Falcataria moluccana inoculated with MycoSilvi grown in post-mining silica sand soil amended with soil ameliorants. Biodiversitas, 21(1): 422-427.

Chen, S., Zhao, H., Zou, C., Li, Y., Chen, Y., Wang, Z., Jiang, Y., Liu, A., Zhao, P., Wang, M. \& Ahammed, G.J. 2017. Combined Inoculation with multiple arbuscular mycorrhizal fungi improves growth, nutrient uptake and photosynthesis in cucumber seedlings. Frontiers in Microbiology, 8: 2516.

Clapp, J.P., Fitter, A.H. \& Merryweather, J.W. 1996. Arbuskular mycorrhizas. In: Methods for the Examination of Organismal Diversity in Soils and Sediments. Hall, G.S., Lasserre, P., Hawksworth, D.L. Oxon (UK) CAB International: Wallingford.

Chung, Ren-shih, Wu. \& Sun-ho. 2008. Effect of corncob compost on plant growth in an acid red soil. Journal Communications in Soil Science and Plant Analysis, 28(9): 673-683.

Delhaize, E. \& Ryan, P.R. 1995. Aluminum toxicity and tolerance in plants. Plant Phytology, 107: 315-321.

Dong, D., Ramsey, M.H. \& Thornton, I. 1995. Effect of soil $\mathrm{pH}$ on $\mathrm{Al}$ availability in soils and its uptake by the soybean plant (Glycine max). Journal of Geochemical Exploration, 55(1): 223-230.

El Kinany, S., Achbani, E., Faggroud, M., Ouahmane, L., El Hilali, R., Haggoud, A. \& Bouamri, R. 2019. Effect of organic fertilizer and commercial arbuscular mycorrhizal fungi on the growth of micropropagated date palm cv. Feggouss. Journal of the Saudi Society of Agricultural Sciences, 18(4): 411-417.

Fini, F. \& Ferrini, F. 2011. Effects of mulching with compost on growth and physiology of Acer campestre L. and Carpinus betulus L. Advances in Horticultural Science, 25(4): 232-238.

Foo, E., Ross, J.J., Jones, W.T. \& Reid, J.B. 2013. Plant hormones in arbuscular mycorrhizal symbioses: an emerging role for gibberellins. Annals of Botany, 111: 769-779.

Furtini-Neto, A.E., Siquiera, J.O., Curi, N. \& Moreira, F.M.S. 2004. Fertilization in native species reforestation. In: Forest Nutrition and Fertilization. Goncalves, J.L.M, Benedetti V (Eds.). Brazil. pp. 351-383.

Guo, Y., Ni, Y. \& Huang, J. 2010. Effects of rhizobium, arbuscular mycorrhiza and lime on nodulation, growth and nutrient uptake of Lucerne in acid purplish soil in China. Tropical Grasslands, 44: 109-114.
Halder, M., Dhar, P.P., Mujib, A.S.M., Khan, M.S., Joardar, J.C. \& Akhter, S. 2015. Effect of arbuscular mycorrhiza fungi inoculation on growth and uptake of mineral nutrition in Ipomoea aquatica. Curr. World Environment, 10(1): 67-75.

Hart, M.M. \& Forsythe, J.A. 2012. Using arbuscular mycorrhizal fungi to improve the nutrient quality of crops; nutritional benefits in addition to phosphorus. Scientia Horticulturae, 148: 206-214.

Hause, B. \& Fester, T. 2005. Molecular and cell biology of arbuscular mycorrhizal symbiosis. Planta, 221: 184-196.

Haynes, R.J. \& Naidu, R. 1998. Influence of lime, fertilizer and manure applications on soil organic matter content and soil physical conditions: a review. Nutrient Cycling in Agroecosystems, 51(2): 123-137.

Hudson, T.L., Fox, F.D. \& Plumlee, G.S. 1999. Metal mining and the environment. American Geological Institut, Alexandria (Virginia).

Jayani, F.M., Budi, S.W. \& Pamoengkas, P. 2018. Response of forest tree species inoculated with MycoSilvi and soil ameliorant addition grown in silica sand. Asian Journal Agricultural and Biology, 6(4): 556-565.

Jung, C., Maeder, V., Funk, F., Beat, F., Sticher, H. \& Frossard, E. 2003. Release of phenols from Lupinus albus $\mathrm{L}$. roots exposed to $\mathrm{Cu}$ and their possible role in $\mathrm{Cu}$ detoxification. Plant Soil, 252: 301-312.

Karmee, S.K. \& Chadha, A. 2005. Preparation of biodiesel from crude oil of Pongomia pinnata. Bioresource Technology, 96: 1425-1429.

Kochian, L.V., Hoekenga, O.A. \& Pineros, M.A. 2004. How do crop plants tolerate acid soils? Mechanisms of aluminum tolerance and phosphorous efficiency. Annual Review Plant Biology, 55: 459-493.

Kohl, L. \& van, der, Heijden. 2016. Arbuskular mycorrhizal fungal species differ in their effect on nutrient leaching. Soil Biology \& Biochemistry, 94: 191-199.

Manjaribe, C., Frasier, C., Rakouth, B. \& Louis, E. 2013. Ecological Restoration and Reforestation of Fragmented Forests in Kianjavato, Madagascar. International Journal of Ecology, 2013(2013).

Maulana, A.F., Turjaman, M., Sato, T., Hashimoto, Y., Cheng, W. \& Tawaraya, K. 2017. Growth response of four leguminous trees to native arbuscular mycorrhizal fungi from tropical forest in Indonesia. International Journal of Plant and Soil Science, 20(3): 1-13. 
Mirkalaei, S.M.M., Ardebili, Z.O. \& Mostafavi, M. 2013. The effects of different organic fertilizers on the growth of lilies (Lillium longiflorum). International Research Journal of Applied and Basic Sciences, 4(1): 181-186.

Mrabet, S.E., Ouahmane, L., Mousadik, A.E. Msanda, F. \& Abbas, Y. 2014. The effectiveness of arbuscular mycorrhizal inoculation and biocompost addition for enhancing reforestation with Argania spinosa in Morocco. Open Journal of Forestry, 4(1): 14-23.

Muindi, E.M., Mrema, J., Semu, E., Mtakwa, P. \& Gachene, C. 2015. Effects of lime-aluminiumphosphate interactions on maize growth and yields in acid soils of the Kenya highlands. American Journal of Agriculture and Forestry, 3(6): 244-252.

Novak, J.M., Ippolito, J.A., Ducey, T.F., Watts, D.W., Spokas, K.A., Trippe, K.M., Sigua, G.C. \& Johnson, M.G. 2018. Remediation of an acidic mine spoil: Miscanthus biochar and lime amendment affects metal availability, plant growth, and soil enzyme activity. Chemosphere, 205: 709-718.

O’Connor, P.J., Smith, S.E. \& Smith, F.A. 2001. Arbuscular mycorrhizal associations in the southern simpson desert. Australian Journal Botany, 49: 493-499.

Pal, A. \& Pandey, S. 2017. Effect of arbuscular mycorrhizal fungi on chemical properties of experimental barren soil with pearl millet (Pennisetum glaucum L.) crop. Science and Technology, 7(3): 82-86.

Percival, G.C., Keary, I.P. \& Novis, K. 2008. The potential of a chlorophyll content SPAD meter to quantify nutrient stress in foliar tissue of sycamore (Acer pseudoplatanus), english oak (Quercus robur), and european beech (Fagus sylvatica). Arboriculture \& Urban Forestry, 34: 89-100.

Rhicardson, A.E., Barea, J.M., McNeill, A.M. \& Prigent-Combaret, C. 2009. Acquisition of phosphorus and nitrogen in the rhizosphere and plant growth promotion by microorganism. Plant Soil, 321: 305-339.

Sahner, J., Budi, S.W., Barus, H., Edy, N., Meyer, M., Corres, M.D. \& Polle, A. 2015. Degradation of Root Community Traits as Indicator for Transformation of Tropical Lowland Rain Forests into Oil Palm and Rubber Plantations. PLoS ONE, 10(9): e0138077.

Sato, T., Ezawa, T., Cheng, W. \& Tawaraya, K. 2015. Release of acid phosphatase from extraradical hyphae of arbuscular mycorrhizal fungus Rhizophagus clarus. Soil Science and Plant Nutrition, 61: 269-274.
Sharma, N., Yadav, K. \& Aggarwal, A. 2017. Role of potassium and arbuscular mycorrhizal fungi in alleviation of water stress on Vigna mungo. Environmental and Experimental Biology, 15: 15-24.

Smith, S.E., Jakobsen, I., Gronlund, M. \& Smith, F.A. 2011. Roles of Arbuscular Mycorrhizas in Plant Phosphorus Nutrition: Interactions between Pathways of Phosphorus Uptake in Arbuscular Mycorrhizal Roots Have Important Implications for Understanding and Manipulating Plant Phosphorus Acquisition. Plant Physiology, 156: 1050-1057.

Subagyo, H.N., Suharta \& Siswanto, A.B. 2004. Agricultural Soil in Indonesia. In: Indonesian Land Resources and Management. A. Adimihardja, L.I. Amien, F. Agus, D. Djaenudin (Eds.). Centre for Soil an Agro-climate Research and Development, Bogor. pp. 21-66.

Teshome, B., Tana, T., Dechassa, N. \& Singh, T.N. 2017. Effect of Compost, Lime and $P$ on Selected Properties of Acidic Soils of Assosa. Biology Agriculture and Healthcare, 7(5): 3444.

Van, Uexkull, H.R. \& Bosshart, R.P. 1989. Management of acid upland soils in Asia. In: Management of Acid Soils in the Humid Tropics of Asia. Craswell, E.T. and Pushparajah, E. (eds). ACIAR Monograph, 13: 2-20.

Wahab, S.A.A. \& Marikar, F.A. 2012. The environmental impact of gold mines: pollution by heavy metals. Central European Journal of Engineering, 2: 304-313.

Wulandari, D., Saridi, Cheng, W. \& Tawaraya, K. 2016. Arbuscular mycorrhizal fungi inoculation improves Albizia saman and Paraserianthes falcataria growth in post-opencast coal mine field in East Kalimantan. Forest Ecology and Management, 67-73.

Yadav, R.D., Jain, S.K., Alok, S., Prajapati, S.K. \& Verma, A. 2011. Pongomia pinata: An overview. International Journal of Pharmaceutical Sciences Research, 2(3): 494-500.

Zatta, P., Lain, E. \& Cagnolini, C. 2000. Effect of aluminium on activity of Krebs cycle enzymes and glutamate dehydrogenase in rat brain homogenate. European Journal of Biochemistry, 267: 3049-3055.

Zhu, X.Q., Wang, C.Y., Chen, H. \& Tang, M. 2014. Effect of arbuscular mycorrhizal fungi on photosynthesis, carbon content and calorific value of black locust seedlings. Photosynthetica, 52: 247-252. 
